\title{
KNOWLEDGE OF GENERAL PRACTITIONAIRE DOCTORS AND MIDWIVES WHO HAS AND HAS NOT ATTENDED NEONATAL RESUSCITATION COURSE HAS NO SIGNIFICANT DIFFERENCE
}

\author{
Vincent Geraldus Enoch Lusida ${ }^{1 a}$, Bambang Pujo Semedi ${ }^{2}$, Bambang Herwanto ${ }^{3}$ \\ ${ }^{1}$ Faculty of Medicine, Universitas Airlangga, Surabaya \\ ${ }^{2}$ Department of Anesthesiology and Reanimation, Faculty of Medicine, Universitas Airlangga/Dr. Soetomo General Academic \\ Hospital, Surabaya \\ ${ }^{3}$ Department of Cardiovascular Medicine, Faculty of Medicine, Universitas Airlangga/Dr. Soetomo Academic Hospital, Surabaya \\ ${ }^{a}$ Corresponding author: vinlusida@gmail.com
}

\begin{abstract}
Introduction: Infant death is most prominent in the neonatal period. The success of neonatal resuscitation practice has many contributing factors. One of which is the health workers' knowledge of the Neonatal Resuscitation Program (NRP) algorithm. Therefore, it is necessary to conduct studies to evaluate the health workers' knowledge of the Neonatal Resuscitation Program who are educated in neonatal resuscitation course and has taken part in Neonatal Life Support practice in primary health care (PHC) Objective: This study aims to analyze the knowledge of general practitioners and midwives who has or has not attended in neonatal resuscitation course in Surabaya PHC Methods and Materials: this research is descriptive, cross-sectional research. All Basic Emergency Obstetric and Newborn Care (BEmONC) PHC in Surabaya which are Jagir PHC, Banyu Urip PHC, Medokan Ayu PHC, Tanah kali Kedinding PHC, Tanjungsari PHC, Balongsari PHC, Sememi PHC, Simomulyo PHC is included in this research from 2018 to 2019. A nine-item questionnaire referenced from The Textbook of Neonatal Resuscitation 7th Edition is given to ten respondents in each BEmONC PHC. Results and Discussion: from the total sample of 78 respondents, $32(41,0 \%)$ receive a high score, 20 $(25,7 \%)$ receive a middle score, and $26(33,3 \%)$ receive a low score. The data shows that there is no significant score difference between respondents who has or has not participate in the NRP course $(\mathrm{p}=0,419)$. Conclusion: There is no correlation between difference knowledge midwives and general practitioners who had and had not attended neonatal resuscitation training at basic emergency obstetric and newborn care in public health center Surabaya.
\end{abstract}

Keywords: Knowledge; Neonatal Resuscitation Program; Neonatal Resuscitation Course; General Practitioner; Midwives

\section{ABSTRAK}

Pendahuluan: Kematian bayi berjumlah paling tinggi pada periode neonatal. Keberhasilan resusitasi neonatus dipengaruhi oleh berbagai faktor dalam suatu institusi kesehatan. Salah satu faktor tersebut adalah pengetahuan tenaga kesehatan tentang algoritma Neonatal Resuscitation Program (NRP). Maka, evaluasi tenaga kesehatan, terutama dokter umum dan bidan yang telah mengikuti pelatihan resusitasi neonatus dan melakukan praktik resusitasi neonatus di puskesmas sangat diperlukan. Tujuan: penelitian ini bertujuan untuk menganalisis pengetahuan dokter umum dan bidan yang sudah dan belum mengikuti pelatihan resusitasi neonatus di puskesmas Surabaya. Metode dan Bahan: penelitian ini adalah penelitian deskriptif dan cross-sectional. Seluruh puskesmas Pelayanan Obstetri Neonatal Emergensi Dasar (PONED) yaitu Puskesmas jagir, Puskesmas Banyu Urip, Puskesmas Medokan Ayu, Puskesmas Tanah kali Kedinding, Puskesmas Tanjungsari, Puskesmas Blongsari, Puskesmas Sememi, Puskesmas Simomulyo adalah puskesmas yang dipakai dalam penelitian ini dari 2018 sampai 2019. Sejumlah sembilan pertanyaan kuesioner yang direferensikan dari Textbook of Neonatal Resuscitation, edisi ketujuh diberikan kepada sepuluh responden di setiap puskesmas. Hasil dan Pembahasan: dari total sampel sejumlah 78, Hasil pengetahuan resusitasi neonatus bidan dan dokter di puskesmas Surabaya yang baik berjumlah 32 responden (41,0\%), yang cukup sebanyak 20 responden $(25,7 \%)$, dan yang kurang berjumlah 26 responden $(33,3 \%)$. Penelitian ini tidak menemukan perbedaan signifikan antara responden yang sudah dan yang belum mengikuti pelatihan resusitasi neonatus $(\mathrm{p}=0,419)$. Kesimpulan: Perbedaan pengetahuan antara bidan dan 
dokter umum yang sudah dan belum mengikuti pelatihan resusitasi neonatus di puskesmas PONED Surabaya tidak signifikan.

Kata kunci: Pengetahuan; Neonatal Resuscitation Program; Pelatihan Resusitasi Neonatus; Dokter Umum; Bidan

Article info: Received 10 December 2019, Received in revised from 13 January 2020, Accepted 04 September 2020

\section{INTRODUCTION}

The neonatal period is the highest death rate out of all periods of life. It is stated by WHO that the death rate of the neonatal period is $46 \%$ among the children mortality under the age of 5. (1) Therefore, WHO conducts a project "Millennium Development Goal (MDG) 4" to decrease the child mortality rate by two thirds from 1990 to 2015. (2)

Neonatal mortality in Indonesia is also monitored and evaluated. Although the neonatal mortality rate in Indonesia is relatively high in 2016 (13.7/1000), the mortality rate has decreased throughout the years. (3) This is also the problem in East Java Province. The neonatal mortality rate in East java is $14 / 1000$ in 2015. (4) Previous studies describe that the Java-Bali region is more prepared than other regions in overall trained health worker, drugs, facilitation, and transportation. (5)

Compared to East Java, Surabaya has a relatively lower infant death rate in 2016 . The infant death rate in Surabaya is 19.55/1000, whereas the infant death rate in East java is 23,60/1000. (6) Despite the lower death rate, Infant death rate in Surabaya is still high. Therefore, more studies are necessary to evaluate causes of neonatal death.

One of the factors that may inhibit the progress is the lack of knowledge by trained health cares in doing neonatal resuscitation. Indonesia's primary health cares, mainly the Basic Emergency Obstetric and Newborn Care(BEmOC) are the first line of health services in handling neonatal resuscitation. In Surabaya, there are $63 \mathrm{PHC}$ and 21 of which helps mothers with labor that requires hospitalization. However, there are only 8 PHCs that has the title of Basic Emergency Obstetric And Newborn Care. (7) Thus these 8 PHCs are responsible for resuscitating neonates from all 63 PHCs when they aren't referred to a hospital.

In this present study, we aim to investigate the knowledge difference of doctors and midwives who have and have not taken a neonatal resuscitation courses. This study may draw more attention to these healthcare's knowledge of neonatal resuscitation and provide the data to conduct more neonatal resuscitation course.

\section{METHOD AND MATERIAL}

This is a descriptive quantitative crosssectional research located at 8 Emergency Neonatal and Obstetrics Services in public health Surabaya in Public Health Center Surabaya These PHCs are Jagir PHC, Banyu Urip PHC, Medokan Ayu PHC, Tanah kali Kedinding PHC, Tanjungsari PHC, Balongsari PHC, Sememi PHC, Simomulyo PHC. The time used for conducting this research may differ for every primary health care, however, generally it is conducted from December 2018 to July 2019. Through stratified random sampling, 10 respondents from each PHC which was filtered through several inclusion and exclusion criteria were asked to answer a questionnaire which was referenced from The Textbook of Neonatal Resuscitation, 7th edition. We divide the occupations by a ratio of 7 midwives to 3 GPs, as the ratio is similar to the population. 
The inclusion and exclusion criteria we used to filter out unsuitable respondents: Inclusion criteria:

1. Respondents must be midwives or general practitioners practicing BEmOC in the Primary Health Care.

2. Respondents have to agree and sign the information for consent and informed consent forms.

Exclusion criteria:

1. Paid leave respondents.

2. Respondents in the process of taking further study.

The 7th edition Textbook of Neonatal Resuscitation is the latest neonatal resuscitation textbook consisting of up-to-date recommendations. It is made by the American Academy of Pediatrics and the American Heart Association.

IBM SPSS Statistics, version 23 was used for statistical analysis. Pearson Product Moment for the validity test and Cronbach's Alpha for the reliability test is used to ensure the questionnaire is valid and reliable. MannWhitney U test, a comparative non-parametric test is used to compare the respondent's knowledge. Differences between respondents who have participated in the NLS course and respondents who have not participated were considered to be significant when the P-value was $<0.05$.

\section{RESULT AND DISCUSSION}

Seventy-Eight subjects have partaken in this questioner about neonatal resuscitation as seen in table 1. Similar research is done in Muhammadyah Gresik Hospital also has a similar percentage of the respondent with adequate knowledge (45.8\%). (8)

Midwives are known to be a partner for women to give them support and education throughout their pregnancy period and their puerperal. Midwives are also responsible for helping women during labor, educating, and detecting complications of mother and child's health. (9) Therefore, there are more midwives than doctors practicing in BEmONC PHCs. This is proven with the data from the Ministry of Health Republic of Indonesia. (10)

Table 1. Characteristics of the Respondents

\begin{tabular}{lcc}
\hline \multicolumn{1}{c}{ Characteristics } & $\begin{array}{c}\text { Frequency } \\
(\mathbf{N = 7 8})\end{array}$ & $\begin{array}{c}\text { Percentage } \\
(\mathbf{\%})\end{array}$ \\
\hline Profession & & \\
$\quad$ Midwife & 57 & 73.1 \\
$\quad$ General Practitioner & 21 & 26.9 \\
\hline NLS Course & & \\
Participation & & \\
$\quad$ Participate & 10 & 12.8 \\
$\quad$ Did not participate & 68 & 87.2 \\
\hline Knowledge & & \\
$\quad$ Good & 32 & 41 \\
$\quad$ Moderate & 20 & 25.7 \\
$\quad$ Bad & 26 & 33.3 \\
\hline
\end{tabular}

The result in table 2 shows that there is no significant difference between these two groups. The grade percentage of respondents who have taken NLS Course in Karanganyar District PHC is similar to the grade percentage in BEmONC Primary Health Care in Surabaya. (11)

Table 2. The Knowledge Based on NLS Course Participation

\begin{tabular}{cccccccccc}
\hline NLS Course & \multicolumn{8}{c}{ Knowledge } \\
\cline { 2 - 10 } Participation & \multicolumn{2}{c}{ Good } & \multicolumn{1}{c}{ Moderate } & \multicolumn{2}{c}{ Bad } & \multicolumn{2}{c}{ Total } \\
& $\mathrm{n}$ & $\%$ & $\mathrm{n}$ & $\%$ & $\mathrm{n}$ & $\%$ & $\mathrm{n}$ & $\%$ \\
\hline Have & 2 & 20.0 & 5 & 50.0 & 3 & 30.0 & 10 & 100.0 \\
Have not & 30 & 44.1 & 15 & 22.1 & 23 & 33.8 & 68 & 100.0 \\
\hline \multicolumn{1}{c}{ P-Value $=\mathbf{0 . 4 1 9}$} \\
\hline
\end{tabular}

There is no significant difference between respondents who participated in the NLS course and respondents who did not participate in the NLS course. Generally, the factors that may contribute to the knowledge of a course is course effectiveness and knowledge retention.

Studies show that there is significance between pre-test and post-test of respondents participating in the NLS course. (12)(13) 
Therefore, the insignificant difference in knowledge may not be caused by NLS course effectiveness, but caused by NLS knowledge retention. Mosley and Shaw also discussed that the knowledge of respondents who practice neonatal resuscitation 5 times in a month have a significant difference to respondents who practice neonatal resuscitation once a month. Knowledge retention is also important for basic life support courses as the knowledge also decreased after 1 month because the fewer the practice. (14)

\section{CONCLUSION}

In conclusion, the knowledge difference between midwives and general practitioners who have participated and have not participated in the NLS course in BEmONC primary health care in Surabaya is not significant. This indifferent knowledge may be caused by inadequate retention of NLS knowledge of midwives and GPs who have participated in the NLS course.

Further research is needed to evaluate the current retention program and determine the appropriate action. Other research is needed to find the most effective retention program to maintain the NLS knowledge.

\section{ACKNOWLEDGEMENT}

This research is funded from independent resources and done with the permission of the Ministry of Health in Surabaya. We express our gratitude to the BEmONC PHC of Surabaya (Medokan Ayu PHC, Jagir PHC, Banyu Urip PHC, Tanjungsari PHC, Balongsari PHC, Tanah Kali Kedinding PHC, Sememi PHC, Simomulyo PHC) for the hospitality and willingness in participating in this research.

\section{Conflict of Interest}

This research does not have any conflict of interest.

\section{REFERENCES}

1. World Health Organization. Neonatal mortality [Internet]. Monograph Online. 2018 [cited 2018 Jun 24]. Available from:

http://www.who.int/gho/child_health/m ortality/neonatal_text/en/

2. World Health Organization. MDG 4: reduce child mortality [Internet]. Monograph Online. 2015 [cited 2018 Jun 22]. Available from: http://www.who.int/topics/millennium_ development_goals/ child_mortality/en/

3. Budijanto D, Kurniawan R, Yudianto, Hardhana B, Siswanti T. Profil Kesehatan Indonesia. Jakarta: Kementerian Kesehatan Republik Indonesia; 2019. 131-132 p.

4. Badan Pusat Statistik. Angka Kematian Neonatal (AKN) Dan Angka Kematian Bayi Per 1000 Kelahiran Menurut Provinsi, 2015-2016 [Internet]. Monograph Online. 2015 [cited 2019 Nov 27]. Available from: https://www.bps.go.id/dynamictable/20 18/06/06/1464/angka-kematianneonatal-akn-dan-angka-kematian-bayiper-1000-kelahiran-menurut-provinsi2012.html

5. Mujiati M, Lestari H, Laelasari E. Kesiapan Puskesmas PONED (Pelayanan Obstetri Neonatal Emergensi Dasar) di Lima Regional Indonesia. Media Penelit dan Pengemb Kesehat [Internet]. 2014;24:36-41. Available from: http://ejournal.litbang.depkes.go.id/inde x.php/MPK/article/view/3485

6. Badan Pusat Statistik. Angka Kematian 
Bayi (AKB) Penduduk Jawa Timur Menurut Kabupaten/Kota, 2012-2016 [Internet]. Monograph Online. 2017. Available from: https://jatim.bps.go.id/statictable/2017/ 06/07/389/angka-kematian-bayi-akbpenduduk-jawa-timur-menurutkabupaten-kota-2012-2016.html

7. Dinas Kesehatan Kota Surabaya. Profil Dinas Kesehatan kota Surabaya [Internet]. Monograph Online. 2020. Available from: http://dinkes.surabaya.go.id/portalv2/pr ofil/profil-dinas-kesehatan-kotasurabaya/

8. Syaiful Y, Choiriyah S. Pengetahuan dan Sikap Perawat dengan Tindakan Resusitasi Neonatus Gawat Nafas. J Ners Community. 2014;5(2):169-73.

9. Ikatan Bidan Indonesia. Definisi [Internet]. Monograph Online. 2016. Available from: https://ibi.or.id/id/article_view/a201501 12004/definisi.html

10. Badan Pengembangan dan Pemberdayaan Sumber Daya Manusia Kesehatan. Rekapitulasi SDM Kesehatan yang Didayagunakan di Fasyankes di Kabupaten Kota Surabaya, Provinsi Jawa Timur [Internet].
Monograph Online. 2016. Available from:

http://bppsdmk.kemkes.go.id/info_sdm k/info/rekap_kab?kab=3578

11. Marlina E, Any A. Analisis Upaya Bidan dalam Penanganan Asfiksia bayi Baru Lahir di Puskesmas Kabupaten Karanganyar. Maternal. 2015;12:39-40.

12. Yuliana A. Efektivitas Pelatihan Resusitasi Neonatus dalam Meningkatkan Pengetahuan dan Keterampilan Mahasiswa Div Bidan Pendidik. J Ilm Bidan. 2015;1(1):35-50.

13. Mosley C, Shaw B. A longitudinal cohort study to investigate the retention of knowledge and skills following attendance on the Newborn Life support course. Arch Dis Child. 2013;98(8):582-6.

14. Widyarani L. Analisis Pengaruh Pelatihan Resusitasi Jantung Paru RJP Dewasa terhadap Retensi Pengetahuan dan Keterampilan RJP pada Mahasiswa Keperawatan di Yogyakarta. J Keperawatan Soedirman. 2018;12:143. 